\title{
Factors Responsible for Cerebral Hypoxia in Hemodialysis Population
}

\author{
A. VALERIANOVA ${ }^{1}$, J. LACHMANOVA ${ }^{2}$, L. KOVAROVA ${ }^{1}$, T. KMENTOVA ${ }^{1}$, \\ M. BARTKOVA ${ }^{2}$, J. MALIK ${ }^{1}$
}

${ }^{1}$ Third Department of Internal Medicine, First Faculty of Medicine Charles University and General University Hospital in Prague, Czech Republic, ${ }^{2}$ Department of Nephrology, First Faculty of Medicine Charles University and General University Hospital in Prague, Czech Republic

Received October 22, 2018

Accepted April 15, 2019

Epub Ahead of Print June 6, 2019

\begin{abstract}
Summary
Brain tissue oxygenation ( $\left.\mathrm{rSO}_{2}\right)$ measured by near-infrared spectroscopy (NIRS) is lower in hemodialysis patients than in the healthy population and is associated with cognitive dysfunction. The involved mechanisms are not known. We conducted this study to identify the factors that influence the $\mathrm{rSO}_{2}$ values in endstage renal disease (ESRD) patients and to describe $\mathrm{rSO}_{2}$ changes during hemodialysis. We included a cohort of ESRD patients hemodialyzed in our institution. We recorded $\mathrm{rSO}_{2}$ using INVOS 5100C oximetry system (Medtronic, Essex, U.K.) and analyzed changes in basic laboratory values and hemodynamic fluctuations. Baseline $\mathrm{rSO}_{2}$ was lower in patients with heart failure $(45.2 \pm 8.3 \%$ vs. $54.1 \pm 7.8 \%, p=0.006)$ and was significantly linked to higher red cell distribution width (RDW) $(r=-0.53, p<0.001)$ and higher BNP level $(r=-0.45, p=0.01)$. The $\mathrm{rSO}_{2}$ value decreased in first $15 \mathrm{~min}$ of hemodialysis, this decrease correlated with drop in white blood count during the same period $(r=0.43, p=0.02$ in $10 \mathrm{~min}, r=0.43, p=0.02$ in $20 \mathrm{~min}$ ). Lower $\mathrm{rSO}_{2}$ values in patients with heart failure and higher RDW suggest that hemodynamic instability combined with vascular changes probably leads to worse cerebral oxygenation in these patients. Decrease of $\mathrm{rSO}_{2}$ in $15^{\text {th }}$ minute of hemodialysis accompanied with a significant drop in leukocyte count could be explained by complement activation.
\end{abstract}

\section{Key words}

Heart failure • Chronic renal failure • Hemodialysis • Cerebral hypoxia

\section{Corresponding author}

A. Valerianova, 3rd Department of Internal Medicine, General University Hospital, First Faculty of Medicine, U Nemocnice 1, 12808 Prague 2, Czech Republic. E-mail: anna.valerianova@vfn.cz

\section{Introduction}

End-stage renal disease (ESRD) patients treated by hemodialysis suffer from tissue ischemia (brain, peripheral muscle), which is aggravated by hemodialysis sessions (Malik et al. 2017). Brain ischemia leads to cognitive decline in hemodialysis patients (Kovarova et al. 2018). Brain oxygenation can be measured non-invasively by the near-infrared spectroscopy (NIRS), which gives the cerebral tissue oxygenation $\left(\mathrm{rSO}_{2}\right)$ (Ito et al. 2015, Matsukawa et al. 2017, Papadopoulos et al. 2013, Hoshino et al. 2014). The near-infrared spectroscopy (NIRS) is a method that estimates regional tissue oxygenation by transcutaneous measurement. It differs from the finger oximetry by using two photoelectrodes - shallow and deep. The data from the shallow electrode is subtracted from the data from the deep electrode. The result $\left(\mathrm{rSO}_{2}\right)$ combines venous, microcirculatory and arterial hemoglobin saturation (McCormick et al. 1991). Although it is known that dialysis patients have considerably lower $\mathrm{rSO}_{2}$ values than healthy controls (Malik et al. 2017, Ito et al. 2015, Hoshino et al. 2014) and that this finding is related to cognitive impairment, responsible mechanisms are not completely understood. Otherwise, NIRS is used mostly for non-invasive cerebral oxygenation monitoring during surgery or critical states (McCormick et al. 1991, Douchet et al. 1996). Lower $\mathrm{rSO}_{2}$ values were linked with worse neurological prognosis in patients after cardiac surgery (Yao et al. 2004, Slater et al. 2009), and with worse survival and neurological outcome in patients after cardiopulmonary resuscitation (Ibrahim et al. 2015, 
Ito et al. 2014). Lower brain oxygenation was also related to symptoms of cerebral hypoxia in de-compensated heart failure patients (Madsen et al. 2000). Anyway, it should be stressed out that there is no threshold value of the "pathological" $\mathrm{rSO}_{2}$ values (Jonsson et al. 2017, Bickler et al. 2017).

Thus, cerebral $\mathrm{rSO}_{2}$ is decreased in ESRD patients and further falls after the initiation of hemodialysis according to our pilot study, but the involved mechanisms are to be elucidated. Therefore, we extended our pilot study with the attempt to get more robust data describing $\mathrm{rSO}_{2}$ changes in ESRD patients and to understand the mechanisms responsible for both lower $\mathrm{rSO}_{2}$ values at baseline and during hemodialysis.

\section{Methods}

We included a cohort of patients in chronic hemodialysis program in our university hospital, who agreed to take part in this study and signed the informed consent. Inclusion criteria were presence of ESRD, clinically stable state and lack of overt dementia or history of stroke. The study was approved by local ethical committee and conforms with the Helsinki Declaration.

The measurements were performed during regular hemodialysis session with no changes of patients' dry weight, medication, or compliance to therapeutic regime.

Recorded demographic characteristics included gender, age, weight, height, comorbidities - coronary artery disease, heart failure, diabetes mellitus, arterial hypertension, dyslipidemia, previous thrombosis or pulmonary embolism - and smoking status.

Basic hemodialysis data was collected (ultrafiltration rate, dry weight, length of dialysis session). We recorded the course of frontal lobe tissue oxygen saturation for $5 \mathrm{~min}$ prior to hemodialysis (= baseline) and then during hemodialysis session, measured by near-infrared spectroscopy (NIRS) using the INVOS 5100C oximetry system (Medtronic, Essex, U.K.). The sampling frequency of this device is 6 seconds. The signal was recorded using one probe placed over the dominant frontal lobe. The data was averaged in 1-minute interval and visualized in a chart. Basic hemodynamic parameters (blood pressure, heart rate) were recorded every $10 \mathrm{~min}$ during first $30 \mathrm{~min}$ of hemodialysis session and then every $60 \mathrm{~min}$ until the end of the dialysis session. The blood pressure (BP) was taken by non-invasive measurement on the non-access upper extremity. The mean arterial blood pressure (MAP) was calculated by the equation: $\mathrm{MAP}=2 / 3$ diastolic $\mathrm{BP}+$ $1 / 3$ systolic BP. Blood samples were taken from the dialysis arteriovenous access before the start of dialysis session, in 10, 20 and $30 \mathrm{~min}$ and at the end of the dialysis session. We analyzed the blood count including red cell distribution width - RDW, the acid base status $\left(\mathrm{pH}\right.$, partial pressure of carbon dioxide $-\mathrm{pCO}_{2}$, serum total carbon dioxide, partial pressure of oxygen $-\mathrm{pO}_{2}$, hemoglobin saturation with oxygen $-\mathrm{SatO}_{2}$ ), serum lactate, brain natriuretic peptide (BNP), serum albumin and protein levels. The measured BNP values were logarithmically transformed to get Gaussian distribution for analysis, the original BNP results are presented as median and quartile range.

The statistical analysis was performed using the STATISTICA Software, version 12 (StatSoft, Inc.). We used the univariate correlation analysis, Chi-square test, paired t-test, ANOVA as appropriate and multiple linear regression analysis. $\mathrm{P}<0.01$ was considered significant for univariate correlation analysis and $\mathrm{p}<0.05$ for the multiple linear regression analysis.

\section{Results}

We included 46 patients in our study, 24 men and 22 women, aged $63.3 \pm 15.6$ years. Dialysis vintage was $46.8 \pm 54.4$ months (range 1-207 months, median 24.4 months), dialysis access flow volume $1076 \pm 548 \mathrm{ml} / \mathrm{min}$. The cause of end stage renal disease was hypertensive nephropathy in 11 patients, diabetic nephropathy in 7 patients, polycystic kidney disease in 5 patients, IgA nephropathy, multiple myeloma and infection in 4 patients, systemic lupus erythematosus, renal cell carcinoma, rapidly progressive glomerulonephritis and tubulointerstitial nephritis in 2 patients, focal segmental nephrosclerosis, membranous glomerulopathy and amyloidosis in 1 patient. Eleven patients $(24 \%)$ had history of coronary artery disease, 8 patients $(17 \%)$ of chronic heart failure, 18 patients (39\%) of diabetes mellitus, 37 patients $(80 \%)$ of arterial hypertension, 19 patients (41 \%) had dyslipidemia, 10 patients $(22 \%)$ had history of previous venous thrombosis or pulmonary embolism. Twenty-two patients (48 \%) were current or former smokers.

\section{Baseline $\mathrm{rSO}_{2}$ measurement}

Mean $\mathrm{rSO}_{2}$ values at baseline were $53 \pm 8 \%$ in our study, which differed only slightly from the pilot study (where it was 52 $\pm 8 \%$ ) (Malik et al. 2017). 
Of the comorbidities, only the presence of heart failure was associated with significantly lower $\mathrm{rSO}_{2}$ values (45.2 $\pm 8.3 \%$ vs. $\left.54.1 \pm 7.8 \%, \mathrm{p}=0.006\right)$.

There was no significant relation between $\mathrm{rSO}_{2}$ value and dialysis vintage, dialysis access blood flow volume, blood pressure or heart rate. Of the laboratory values, $\mathrm{rSO}_{2}$ decreased significantly with increasing both RDW $(\mathrm{r}=-0.53, \mathrm{p}<0.001)$ and $\mathrm{BNP}$ $(r=-0.45, p=0.01)$ for all baseline values and results of univariate analysis (Table 1 ).

We tested several multiple regression models by adding age, heart failure, BNP and RDW (2-3 variables for each model). In all of them, age was not significantly related to $\mathrm{rSO}_{2}$. The presence of heart failure and higher BNP lost significance when RDW was added, RDW remained the strongest determinant of $\mathrm{rSO}_{2}$.

$\mathrm{rSO}_{2}$ changes during hemodialysis

Baseline and end-of dialysis $\mathrm{rSO}_{2}$ values did not differ significantly $(52.6 \pm 8.5 \%$ vs. $52.1 \pm 9.0 \%, \mathrm{p}=0.53)$.
The time course of $\mathrm{rSO}_{2}$ during hemodialysis is depicted in Figure 1. We observed two drops of $\mathrm{rSO}_{2}$ value during hemodialysis, the first one in $15^{\text {th }}$ minute after the start of hemodialysis (to $51.3 \pm 8.7 \%, \mathrm{p}=0.003$ vs. baseline), the second one after 3 hours $(50.7 \pm 9.6 \%, \mathrm{p}=0.01$ vs. baseline).

The decrease in brain tissue oxygenation 10 and 20 min after the start of hemodialysis was significantly accompanied by the decrease of leukocyte count $(\mathrm{r}=0.43$, $\mathrm{p}=0.02$ in $10 \mathrm{~min}, \mathrm{r}=0.43, \mathrm{p}=0.02$ in $20 \mathrm{~min})$. The leukocyte count dropped significantly in $10^{\text {th }}$ and $20^{\text {th }}$ minute (from $6.2 \pm 2 \times 10^{3} / \mu 1$ at baseline, to $5.2 \pm 2.0 \times 10^{3} / \mu 1, \quad \mathrm{p}=0.00001$ in $10^{\text {th }}$ minute and $5.4 \pm 1.9 \times 10^{3} / \mu 1, \quad \mathrm{p}<0.0000001$ in $20^{\text {th }}$ minute, respectively, compared to baseline). Apart from this, the changes of $\mathrm{rSO}_{2}$ in $10^{\text {th }}, 20^{\text {th }}$ and $30^{\text {th }}$ minute of hemodialysis and at the end of hemodialysis did not have any significant relation with any of the measured laboratory and hemodynamic parameters (Table 2).

Table 1. Baseline data and their relation to $\mathrm{rSO}_{2}$ changes

\begin{tabular}{|c|c|c|c|}
\hline \multirow[t]{2}{*}{ Parameter } & \multirow{2}{*}{$\begin{array}{c}\text { Baseline value } \\
\text { mean } \pm \mathrm{SD}\end{array}$} & \multicolumn{2}{|c|}{ Correlation with $\mathrm{rSO}_{2}$} \\
\hline & & $\mathbf{r}$ & $\mathbf{p}$ \\
\hline Age (years) & $63 \pm 16$ & -0.27 & 0.07 \\
\hline Dialysis vintage (months) & $46.8 \pm 54.4$ & -0.19 & 0.20 \\
\hline Qva (ml/min) & $1076 \pm 548$ & 0.12 & 0.46 \\
\hline Residual diuresis (ml/day) & $464 \pm 507$ & 0.32 & 0.03 \\
\hline White blood count $(x 103 / \mu l)$ & $6.5 \pm 2.5$ & 0.20 & 0.18 \\
\hline Red blood count $(x 106 / \mu l)$ & $3.2 \pm 0.6$ & 0.27 & 0.07 \\
\hline Hematocrit (\%) & $31 \pm 4$ & 0.21 & 0.17 \\
\hline Hemoglobin $(g / l)$ & $98.7 \pm 14.8$ & 0.18 & 0.24 \\
\hline Red cell distribution width (\%) & $15.5 \pm 1.9$ & -0.53 & $<0.001$ \\
\hline Platelet count $(x 103 / \mu l)$ & $196 \pm 67$ & 0.03 & 0.84 \\
\hline$p H$ & $7.35 \pm 0.04$ & -0.36 & 0.04 \\
\hline$p \mathrm{CO}_{2}(\mathrm{kPa})$ & $5.1 \pm 0.6$ & 0.31 & 0.08 \\
\hline $\mathrm{pO}_{2}(\mathrm{kPa})$ & $10.8 \pm 3.1$ & -0.08 & 0.68 \\
\hline Hemoglobin saturation by $\mathrm{O}_{2}$ & $90.2 \pm 14.3$ & -0.08 & 0.67 \\
\hline Lactate (mmol/l) & $1.1 \pm 0.5$ & -0.18 & 0.35 \\
\hline Serum protein $(g / l)$ & $63.3 \pm 6.6$ & 0.17 & 0.26 \\
\hline Albumin $(g / l)$ & $38 \pm 5.8$ & 0.30 & 0.04 \\
\hline Brain natriuretic peptide* (ng/l) & $573(1165)$ & -0.45 & 0.01 \\
\hline Systolic BP $(\mathrm{mmHg})$ & $148 \pm 24$ & 0.13 & 0.38 \\
\hline Diastolic BP ( $\mathrm{mmHg})$ & $77 \pm 16$ & 0.27 & 0.07 \\
\hline Mean BP $(\mathrm{mmHg})$ & $89 \pm 16$ & 0.23 & 0.12 \\
\hline Heart rate (bpm) & $78 \pm 13$ & -0.02 & 0.87 \\
\hline
\end{tabular}

$\mathrm{BP}=$ blood pressure, $\mathrm{pO}_{2}=$ partial pressure of oxygen, $\mathrm{pCO}_{2}=$ partial pressure of carbon dioxide, $\mathrm{rSO}_{2}=$ regional oxygen saturation, Significant results are in bold. * Brain natriuretic peptide results are presented as median (quartile range). 


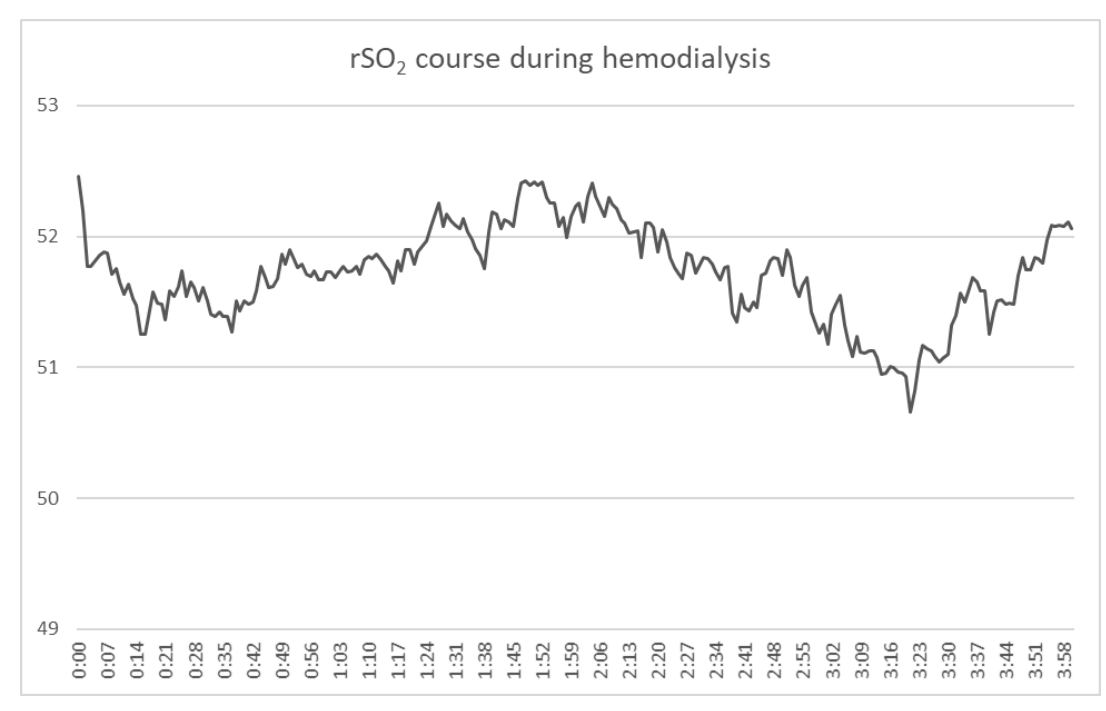

Fig. 1. Cerebral oxygenation course during hemodialysis. The graph depicts the averaged $\mathrm{rSO}_{2}$ values. Individual courses of $\mathrm{rSO}_{2}$ values during hemodialysis vary.

Table 2. Changes of cerebral oxygenation, laboratory and hemodynamic parameters during hemodialysis

\begin{tabular}{|c|c|c|c|c|c|}
\hline \multirow[t]{2}{*}{ Parameter } & \multicolumn{5}{|c|}{ Time } \\
\hline & Baseline & $10 \mathrm{~min}$ & $20 \mathrm{~min}$ & $30 \mathrm{~min}$ & End \\
\hline$r \mathrm{SO}_{2}(\%)$ & $52.6 \pm 8.4$ & $51.8 \pm 8.8^{*}$ & $51.5 \pm 8.8 *$ & $51.7 \pm 8.8$ & $52.1 \pm 8.9$ \\
\hline White blood count $(x 103 / \mu l)$ & $6.2 \pm 2.0$ & $5.2 \pm 2.0 \dagger$ & $5.4 \pm 1.9 \dagger$ & $5.8 \pm 2.0 \dagger$ & $6.0 \pm 2.2$ \\
\hline Red blood count $(x 106 / \mu l)$ & $3.2 \pm 0.4$ & $3.2 \pm 0.4$ & $3.2 \pm 0.4$ & $3.3 \pm 0.5$ & $3.6 \pm 0.6 \dagger$ \\
\hline Hemoglobin $(g / l)$ & $98.6 \pm 12.7$ & $97.8 \pm 12.0$ & $98.8 \pm 11.5$ & $101.4 \pm 15.1$ & $110.2 \pm 16.1 \dagger$ \\
\hline Hematocrit (\%) & $31 \pm 5$ & $30 \pm 4^{*}$ & $31 \pm 4$ & $31 \pm 5$ & $34 \pm 5 \dagger$ \\
\hline pH & $7.35 \pm 0.03$ & $7.34 \pm 0.04$ & $7.35 \pm 0.04$ & $7.37 \pm 0.04 * *$ & $7.46 \pm 0.05 \dagger$ \\
\hline $\mathrm{pCO}_{2}(\mathrm{kPa})$ & $5.0 \pm 0.6$ & $5.4 \pm 0.5 \dagger$ & $5.5 \pm 0.6 \dagger$ & $5.4 \pm 0.5 \dagger$ & $5.0 \pm 0.5$ \\
\hline $\mathrm{pO}_{2}$ & $11.6 \pm 2.5$ & $12.2 \pm 2.8$ & $11.9 \pm 2.6$ & $11.7 \pm 2.3$ & $11.5 \pm 2.6$ \\
\hline Systolic BP (mmHg) & $149 \pm 22$ & $134 \pm 17 \dagger$ & $136 \pm 17 \dagger$ & $139 \pm 20 \dagger$ & $127 \pm 23 \dagger$ \\
\hline Diastolic BP (mmHg) & $78 \pm 13$ & $73 \pm 13 * *$ & $72 \pm 11 \dagger$ & $72 \pm 13 \dagger$ & $70 \pm 15 \dagger$ \\
\hline Mean BP (mmHg) & $102 \pm 14$ & $94 \pm 12 \dagger$ & $93 \pm 11 \dagger$ & $95 \pm 13 \dagger$ & $89 \pm 16 \dagger$ \\
\hline Heart rate (bpm) & $76 \pm 13$ & $70 \pm 12 \dagger$ & $70 \pm 12 * *$ & $72 \pm 11$ & $76 \pm 14$ \\
\hline
\end{tabular}

Continuous variables are shown as mean \pm SD. $* p<0.05$ for the comparison with baseline, $* * p<0.01$ for the comparison with baseline, $+p<0.001$ for the comparison with baseline

We observed that some patients had more pronounced $\mathrm{rSO}_{2}$ changes during hemodialysis than others. To analyze possible physiological importance, we divided the patients into two groups according to the stability of $\mathrm{rSO}_{2}$ value during the hemodialysis sessions ("stable" vs. "unstable"). The median value of $\mathrm{rSO}_{2}$ fluctuation and thus the cut-off value was 10 percent points. The "unstable" patients had lower $\mathrm{rSO}_{2}$ values before hemodialysis $(49.9 \pm 8.6 \%$ vs. $56.1 \pm 7.3 \%$, $\mathrm{p}=0.01$ ), during hemodialysis and at the end of hemodialysis session $(56.9 \pm 6.6 \%$ vs. $48.3 \pm 8.9 \%$, $\mathrm{p}=0.001$ ) (Table 3). for details. The "unstable" group had significantly higher RDW than the stable group $(16.0 \pm 2.2$ vs. $14.8 \pm 1.4, \mathrm{p}=0.04)$ and significantly higher BNP level $(p=0.002)$. There was no other significant difference in observed laboratory and hemodynamic parameters or ultrafiltration. Patients with known chronic heart failure were more likely to be in the unstable group ( $88 \%$ vs. $50 \%, \mathrm{p}=0.05$ ).

\section{Discussion}

This study confirmed low baseline cerebral $\mathrm{rSO}_{2}$ values in one a large of the largest hemodialysis patients' cohorts. Of potential involved mechanisms, higher RDW values were the strongest determinant of lower baseline 
Table 3. Differences in cerebral $\mathrm{rSO}_{2}$ value during hemodialysis in "stable" and "unstable" group of patients.

\begin{tabular}{lccc}
\hline Time of hemodialysis & $\begin{array}{c}\mathbf{r S O}_{\mathbf{2}}(\mathbf{\%}) \\
\text { "Stable" group }\end{array}$ & $\begin{array}{c}\text { rSO } \mathbf{( \% )} \\
\text { "Unstable" group }\end{array}$ & $\begin{array}{l}\text { P value } \\
\text { Baseline }\end{array}$ \\
10 minutes & $56.1 \pm 7.3$ & $49.9 \pm 8.6$ & 0.01 \\
20 minutes & $55.9 \pm 7.1$ & $48.5 \pm 9.0$ & 0.005 \\
30 minutes & $55.8 \pm 6.5$ & $48.0 \pm 9.2$ & 0.003 \\
1 hour & $56.1 \pm 6.5$ & $48.3 \pm 9.1$ & 0.002 \\
2 hours & $56.3 \pm 6.7$ & $48.3 \pm 9.2$ & 0.002 \\
3 hours & $56.4 \pm 6.0$ & $49.1 \pm 9.4$ & 0.004 \\
End & $55.8 \pm 7.3$ & $48.1 \pm 9.4$ & 0.005 \\
\hline
\end{tabular}

Unpaired t-test was used for comparison. "Stable" patients had $\mathrm{rSO}_{2}$ variation $<10 \%$, unstable $>10 \%$; see the text for further explanation

$\mathrm{rSO}_{2}$, presence of congestive heart failure and higher values of $\mathrm{BNP}$ also predicted lower $\mathrm{rSO}_{2}$. The values of $\mathrm{rSO}_{2}$ decreased at the beginning of hemodialysis and then after the $3^{\text {rd }}$ hour, the first $\mathrm{rSO}_{2}$ decline was related to the decrease of leukocyte count. Patients with congestive heart failure, higher BNP values and higher RDW had more pronounced $\mathrm{rSO}_{2}$ fluctuation during hemodialysis.

It is already known that decompensated heart failure leads to $\mathrm{rSO}_{2}$ decrease in non-CKD patients (Madsen et al. 2000). Thus, patients with cardiorenal syndrome type 2 or 4 according to Ronco (Granata et al. 2009), characterized by the presence of both heart failure and CKD (Cruz et al. 2013), are prone to circulatory instability. Two mechanisms could explain lower $\mathrm{rSO}_{2}$ values in these patients: cerebral blood flow decrease due to lower cardiac output and dysfunction of cerebral vascular autoregulation, especially in response to changes of carbon dioxide level (Havakuk et al. 2017). Described changes could prolong cerebral blood transition time, which may be responsible for increased oxygen uptake by the brain tissue. NIRS combines arterial and venous blood hemoglobin saturation with the ratio $1: 3$, so $\mathrm{rSO}_{2}$ was decreased mainly due to lower blood hemoglobin saturation in the venous blood due to slower blood flow and thus higher extraction of oxygen from hemoglobin.

Interestingly, $\mathrm{rSO}_{2}$ values were lower in patients with higher red cell distribution width (RDW), higher RDW was also associated with bigger $\mathrm{rSO}_{2}$ fluctuations during hemodialysis. Increase in RDW was previously reported in CKD patients (Ujszaszi et al. 2013, Docci et al. 1989). RDW describes the heterogeneity in erythrocytes size, high variability indicates dysfunctional erythropoiesis or shorter erythrocyte lifespan (Ujszaszi et al. 2013). RDW has been extensively studied recently: it was linked to malnutrition, inflammation, oxidative stress (Tekce et al. 2014) - all these states are present in ESRD patients on hemodialysis. Shorter erythrocyte lifespan has been documented in hemodialysis patients, it was linked to intradialytic hypoxemia resulting in lower erythrocyte resilience to oxidative stress (MeyringWösten et al. 2016). Higher RDW is a strong predictor of increased all-cause mortality, similar to albumin and even stronger than hemoglobin or ferritin in ESRD (Vashistha et al. 2016), coronary artery disease or other conditions. Nevertheless, no clear explanation of the detrimental effect of higher RDW is available - although some authors linked higher RDW to decreased red cell deformability and thus slower capillary flow (Patel et al. 2013), others did not confirm such association (Vaya et al. 2015). Therefore, higher RDW could be only an epiphenomenon instead of having direct causative role.

We observed a decrease of brain $\mathrm{rSO}_{2}$ after the start of dialysis session, reaching its minimum in $15 \mathrm{~min}$. These results confirm the observation made in our pilot study (Malik et al. 2017), although the decrease seems to occur sooner in the larger group and is less steep. A decrease in arterial oxygen saturation $\left(\mathrm{SaO}_{2}\right)$ after the beginning of hemodialysis was described previously by Campos et al. (2016), however, the $\mathrm{SaO}_{2}$ value reached the minimum later in his study. In our study, the drop in $\mathrm{rSO}_{2}$ value was significantly related only to the drop in leukocytes. Possible explanation is the activation of complement - its maximal activation develops $15 \mathrm{~min}$ after the start of hemodialysis (Yigla et al. 2006) and it is affected by the contact of blood with dialysis membrane. 
The transient leukopenia during hemodialysis is usually explained by transient sequestration of leukocytes in pulmonary circulation mediated by complement activation (Remuzzi et al. 2014). The activation of complement may result in pulmonary dysfunction in dialysis patients (Craddock et al. 1977), however, we do not have any record of respiration problems in our patient group. In this study, we observed a second and even more pronounced drop of $\mathrm{rSO}_{2}$ values after 3 hours since hemodialysis initiation. As far as this is a new observation, not apparent in our pilot study, we did not have related laboratory data that could explain it. We did not observe any significant relation with changes of blood pressure either. Anyway, in a recently published study using position-emission tomography (Polinder-Bos et al. 2018), cerebral blood flow significantly decreases towards the end of hemodialysis session.

Blood pressure dropped significantly after the start of hemodialysis and further decreased till its end, as is typical. Statistically, we did not find any relation between blood pressure (changes) and $\mathrm{rSO}_{2}$. This finding suggests that even in this multimorbid elderly population, the cerebral autoregulation mechanisms are able to maintain stable cerebral blood flow in the wide range of blood pressure values, as in physiological conditions (Lassen 1959).

We are aware that the study has some limitations. Mainly it is its cross-sectional character that does not allow us to evaluate the changes of $\mathrm{rSO}_{2}$ in longer time period. Nevertheless, up to now there is very limited data about $\mathrm{rSO}_{2}$ in hemodialysis population and thus cross-sectional studies are important first steps.

\section{Conflict of Interest}

There is no conflict of interest.

\section{Acknowledgements}

This study was supported by grant n. 1178218 of the Charles University Grant Agency and by the grant of the Agency of Health Research of the Czech Republic 17-31796A.

\section{References}

BICKLER P, FEINER J, ROLLINS M, MENG L: Tissue oximetry and clinical outcomes. Anesth Analg 124: 72-82, 2017.

CAMPOS I, CHAN L, ZHANG H, DEZIEL S, VAUGHN C, MEYRING-WÖSTEN A, KOTANKO P: Intradialytic hypoxemia in chronic hemodialysis patients. Blood Purif 41: 177-187, 2016.

CRADDOCK PR, FEHR J, BRIGHAM KL, KRONENBERG RS, JACOB HS: Complement and leukocyte-mediated pulmonary dysfunction in hemodialysis. $N$ Engl J Med 296: 769-774, 1977.

CRUZ DN, SCHMIDT-OTT KM, VESCOVO G, HOUSE AA, KELLUM JA, RONCO C, MCCULLOUGH PA: Pathophysiology of cardiorenal syndrome type 2 in stable chronic heart failure: workgroup statements from the eleventh consensus conference of the Acute Dialysis Quality Initiative (ADQI). Contrib Nephrol 182: 117-136, 2013.

DOCCI D, DELVECCHIO C, GOLLINI C, TURCI F, BALDRATI L, GILLI P: Red blood cell volume distribution width (RDW) in uraemic patients on chronic hemodialysis. Int J Artif Organs 12: 170-174, 1989.

DOUCHET MP, COUPPIE P, CHANTREL F, KUNTZ C, HANNEDOUCHE T: Diastolic dysfunction in chronic renal failure patients under hemodialysis. Ann Cardiol Angeiol (Paris) 45: 589-592, 1996.

GRANATA A, ANDRULli S, FIORINI F, LOGIAS F, FIGUERA M, MIGNANI R, BASILE A, FIORE CE: Persistent left superior vena cava: what the interventional nephrologist needs to know. J Vasc Access 10: 207-211, 2009.

HAVAKUK O, KING KS, GRAZETTE L, YOON AJ, FONG M, BREGMAN N, ELKAYAM U, KLONER RA: Heart failure-induced brain injury. J Am Coll Cardiol 69: 1609-1616, 2017.

HOSHINO T, OOKAWARA S, GOTO S, MIYAZAWA H, ITO K, UEDA Y, KAKU Y, HIRAI K, NABATA A, MORI H, YOSHIDA I, TABEI K: Evaluation of cerebral oxygenation in patients undergoing long-term hemodialysis. Nephron Clin Pract 126: 57-61, 2014.

IBRAHIM AW, TRAMMEL AR, AUSTIN H, BARBOUR K, ONUORAH E, HOUSE D, MILLER HL, TUTT C, COMBS D, PHILLIPS R, DICKERT NW, ZAFARI AM: Cerebral oximetry as a real-time monitoring tool to assess quality of in-hospital cardiopulmonary resuscitation and post cardiac arrest care. J Am Heart Assoc 4: e001859, 2015. 
ITO K, OOKAWARA S, UEDA Y, GOTO S, MIYAZAWA H, YAMADA H, KITANO T, SHINDO M, KAKU Y, HIRAI K, YOSHIDA M, HOSHINO T, NABATA A, MORI H, YOSHIDA I, KAKEI M, TABEI K: Factors affecting cerebral oxygenation in hemodialysis patients: cerebral oxygenation associates with $\mathrm{pH}$, hemodialysis duration, serum albumin concentration, and diabetes mellitus. PLoS One 10: e0117474, 2015.

ITO N, NISHIYAMA K, CALLAWAY CW, ORITA T, HAYASHIDA K, ARIMOTO H, ABE M, ENDO T, MURAI A, ISHIKURA K, YAMADA N, MIZOBUCHI M, ANAN H, OKUCHI K, YASUDA H, MOCHIZUKI T, TSUJIMURA Y, NAKAYAMA T, HATANAKA T, NAGAO K, J-POP REGISTRY INVESTIGATORS: Noninvasive regional cerebral oxygen saturation for neurological prognostication of patients with out-of-hospital cardiac arrest: a prospective multicenter observational study. Resuscitation 85: 778-784, 2014.

JONSSON M, LINDSTRÖM D, WANHAINEN A, DJAVANI GIDLUND K, GILLGREN P: Near infrared spectroscopy as a predictor for shunt requirement during carotid endarterectomy. Eur J Vasc Endovasc Surg 53: 783-791, 2017.

KOVAROVA L, VALERIANOVA A, KMENTOVA T, LACHMANOVA J, HLADINOVA Z, MALIK J: Low cerebral oxygenation is associated with cognitive impairment in chronic hemodialysis patients. Nephron 139: 113-119, 2018.

LASSEN NA: Cerebral blood flow and oxygen consumption in man. Physiol Rev 39: 183-238, 1959.

MADSEN PL, NIELSEN HB, CHRISTIANSEN P: Well-being and cerebral oxygen saturation during acute heart failure in humans. Clin Physiol 20: 158-164, 2000.

MALIK J, KUDLICKA J, LACHMANOVA J, VALERIANOVA A, ROCINOVA K, BARTKOVA M, TESAR V: Tissue ischemia worsens during hemodialysis in end-stage renal disease patients. $J$ Vasc Access 18: 47-51, 2017.

MATSUKAWA S, HAMADA M, MIZOTA T: Low preoperative regional cerebral oxygen saturation in hemodialysis patients. JA Clin Rep 3: 13, 2017.

MCCORMICK PW, STEWART M, GOETTING MG, BALAKRISHNAN G: Regional cerebrovascular oxygen saturation measured by optical spectroscopy in humans. Stroke 22: 596-602, 1991.

MEYRING-WÖSTEN A, ZHANG H, YE X, FUERTINGER DH, CHAN L, KAPPEL F, ARTEMYEV M, GINSBERG N, WANG Y, THIJSSEN S, KOTANKO P: Intradialytic hypoxemia and clinical outcomes in patients on hemodialysis. Clin J Am Soc Nephrol 11: 616-625, 2016.

PAPADOPOULOS G, DOUNOUSI E, PAPATHANASIOU A, PAPATHANAKOS G, TZIMAS P: Cerebral oximetry values in dialyzed surgical patients: a comparison between hemodialysis and peritoneal dialysis. Ren Fail 35 : $855-859,2013$.

PATEL KV, MOHANTY JG, KANAPURU B, HESDORFFER C, ERSHLER WB, RIFKIND JM: Association of the red cell distribution width with red blood cell deformability. Adv Exp Med Biol 765: 211-216, 2013.

POLINDER-BOS HA, GARCIA DV, KUIPERS J, ELTING JWJ, ARIES MHJ, KRIJNEN WP, GROEN H, WILLEMSEN ATM, VAN LAAR PJ, STRIJKERT F, LUURTSEMA G, SLART RHJA, WESTERHUIS R, GANSEWOORT RT, GAILLARD CAJM, FRANSSEN CFM: Hemodialysis induces an acute decline in cerebral blood flow in elderly patients. J Am Soc Nephrol 29: 1317-1325, 2018.

REMUZZI A, MANINI S: Computational model for prediction of fistula outcome. J Vasc Access 15 (Suppl 7): S64-S69, 2014.

SLATER JP, GUARINO T, STACK J, VINOD K, BUSTAMI RT, BROWN JM $3^{\text {rd }}$, RODRIGUEZ AL, MAGOVERN CJ, ZAUBLER T, FREUNDLICH K, PARR GV: Cerebral oxygen desaturation predicts cognitive decline and longer hospital stay after cardiac surgery. Ann Thorac Surg 87: 36-44, 2009.

TEKCE H, KIN TEKCE B, AKTAS G, TANRISEV M, SIT M: The evaluation of red cell distribution width in chronic hemodialysis patients. Int J Nephrol 2014: 754370, 2014.

UJSAZASZI A, MOLNAR MZ, CZIRA ME, NOVAK M, MUCSI I: Renal function is independently associated with red cell distribution width in kidney transplant recipients: a potential new auxiliary parameter for the clinical evaluation of patients with chronic kidney disease. Br J Haematol 161: 715-725, 2013.

VASHISTHA T, STREJA E, MOLNAR MZ, RHEE C, MORADI H, SOOHOO M, KOVESDY CP, KALANTARZADEH K: Red cell distribution width and mortality in hemodialysis patients. Am J Kidney Dis 68: 110-121, 2016. 
VAYA A, RIVERA L, DE LA ESPIRELLA R, SANCHEZ F, SUESCUN M, HERNANDEZ JL, FACILA L: Red blood cell distribution width and erythrocyte deformability in patients with acute myocardial infarction. Clin Hemorheol Microcirc 59: 107-114, 2015.

YAO FS, TSENG CC, HO CY, LEVIN SK, ILLNER P: Cerebral oxygen desaturation is associated with early postoperative neuropsychological dysfunction in patients undergoing cardiac surgery. $J$ Cardiothorac Vasc Anesth 18: 552-558, 2004.

YIGLA M, ABASSI Z, REISNER SA, NAKHOUL F: Pulmonary hypertension in hemodialysis patients: an unrecognized threat. Semin Dial 19: 353-357, 2006. 